\title{
Morphometric Study of Atypical Lumbar Vertebrae and their Clinical Significance
}

\section{ABSTRACT}

Introduction: Lumbar pedicles are short and strong. They form an important part of lumbar spine and play role in transmission of weight from neural arch to the anterior part of vertebral column. Fractures, tumours and degenerative diseases of lumbar vertebrae are common. Pedicle screw fixation is needed to stabilise the vertebrae if required. Only few studies are available for atypical lumbar vertebrae.

Aim: To determine the various morphometric measurements of fifth lumbar vertebrae and to discuss the various applied aspects of the study.

Materials and Methods: This cross-sectional study was conducted for a period of one year from March 2016 to February 2017. Eighty-five adult human fifth lumbar vertebrae were identified with its atypical features and were examined. Various morphometric measurements- pedicle length, pedicle height and pedicle width, inter pedicle distance, transverse pedicle angle, sagital pedicle angle, chord length, vertebral body height, vertebral body width and vertebral canal measurements were taken using sliding vernier caliper with a least count of $0.1 \mathrm{~mm}$. The data were entered in Microsoft excel and were analysed.

Results: A total of 85 fifth lumbar vertebrae were examined. Mean Pedicle Height of L5 vertebrae on both the sides were equal $(8.4 \pm 3.74)$. Mean pedicle length of L5 vertebrae and mean transverse pedicular angle of $L 5$ vertebrae were more on the right side than on the left side. Mean pedicle width, mean sagital pedicular angle and chord length of L5 vertebrae were more on the left side than on the right side in this study. All the measurements were compared with previous authors and found to have similar results.

Conclusion: Various morphometric measurements of pedicle of fifth lumbar vertebrae were taken in this study. These morphometric knowledge of the pedicles may be helpful for the orthopaedic surgeons and radiologists for proper selection of the pedicle screw and operative repair.

\section{INTRODUCTION}

There are five lumbar vertebrae between the rib cage and the pelvis. The largest segments of the vertebral column are lumbar vertebrae and are characterised by the presence of accessory tubercles in transverse processes and mammillary tubercles in superior articular facets and by the absence of foramen transversarium in the transverse process (as only found in cervical region) and by the absence of facets on the sides of the body (as only found in thoracic region). They are designated L1-L5. The lumbar vertebrae support the weight of the body and permit movement [1]

Lumbar vertebral pedicles are short, thick and flat dorsal projections from superior part of the body at the junction of its lateral and dorsal surface. Pedicles form the concavity by the curved superior and inferior borders. Superior vertebral notch is shallower than inferior. When vertebrae articulate by the intervertebral disc and facet joints, these adjacent vertebral notches contribute to formation of intervertebral foramen. The foramen contains a segmental mixed spinal nerve and its sheaths, 2-4 recurrent meningeal nerves, variable number of spinal arteries and plexiform venous connections between the internal and external vertebral venous plexus. These structures particularly the nerves may be affected by trauma or diseases affecting the adjacent tissue. The complete perimeter of an intervertebral foramen consists of the notches, dorsal aspects of parts of adjacent vertebral bodies, the intervertebral disc and the capsule of the plane synovial facet joints [1].

The fifth lumbar vertebrae is the only atypical lumbar vertebrae differs from others by having massive body, its anterior surface is more extensive than posterior surface, transverse processes are substantial and they encroach on the sides of the body from the junctions of pedicles and laminae and the space between inferior articular processes are wider than that of superior articular processes [2]. Pedicles are thick, strong projections from the junction of lateral and dorsal surface of body of lumbar vertebrae. They are made up of inner cancellous and outer cortical bone. Pedicles have an important role in weight transmission from neural arch to anterior part of vertebral column in lumbar spine. Pedicle of fifth lumbar vertebrae helps in forward slide of L5 over S1. In the lumbar region, where the concavity is posterior, a part of compressive force of anterior column is transmitted to posterior [3].

Low back pain is a major public health problem all over the world. An estimated $75 \%$ of all the people may experience back pain at some time in their lives out of which most of them recover without surgery while $3-5 \%$ of the patient's present herniated disc and $1-2 \%$ have compression of nerve root. Treatment can be conservative or by surgical decompression-laminectomy in persons experiencing severe pain, claudication, neurological deficit or Myelopathy [4].

Fracture of lumbar pedicles is common in older age group due to osteoporosis and requires open surgical or percutaneous pedicle screw fixation to stabilise the vertebrae. Hence morphometric knowledge of lumbar pedicle is important [5]. Transpedicle fixation of the spine is a safe way of gaining effective vertebral stabilisation in the management of different spinal ailments fracture in lumbar spine, removal of tumours in vertebral bodies, gross spondylolesthesis and lumbar unsteadiness [6]. Fracture of the pedicle might result from the usage of relatively oversized screw. Hence, choice of the screw for operation is determined by the minimum diameter of the pedicle [7]. Transpedicle screws enable devices like plates, rods or wires to be applied to spine for fixation. The integrity of the pedicles and vertebral 
body is important for the stability of pedicle screw. Understanding the morphometry of lumbar pedicles and anatomy of adjacent neural structures is very much necessary to reduce intraoperative and postoperative complications. Various causes have been attributed to low backache, but lumbar canal stenosis is one of the causative factors of great interest. In "lumbar stenosis" especially in cases where cauda equina may be compressed within the lumbar spinal canal by constriction or narrowing of the bony ring of the canal, in contrast to impingement by soft tissues. Stenosis of the spinal canal is due to decreased sagital diameter and reduced interpedicular distance [8]. Morphometric study of body of fifth lumbar vertebrae is important for Neurosurgeons, Radiologists, Orthopaedicians and Anatomists. Posterior approach through the pedicle provides direct access to diseases of spine. Measurement of body of fifth lumbar vertebrae is important to avoid complications in the postoperative period [9].

Hence, main objective of the present study was to measure various morphometric data of fifth lumbar vertebrae especially for successful pedicle screw fixation and to discuss its role in quantification of spinal stenosis.

\section{MATERIALS AND METHODS}

This cross-sectional study was conducted on 85 dry adult human lumbar vertebrae from Department of Anatomy, PSG Institute of Medical Sciences and Research, Coimbatore, India for a period of one year from March 2016 to February 2017. After obtaining Ethical committee approval (EIC 15/170).

Inclusion criteria: All undamaged fifth lumbar vertebrae and vertebrae without any changes were taken for study and various morphometric data were measured.

Exclusion criteria: Among 89, fifth lumbar vertebrae, four damaged vertebrae and vertebrae with pathological changes were excluded from the study.

The following parameters were measured:

1. Pedicle length (both on the right and left sides) [5]- measured at the points from the attachment of pedicle to vertebral body and to the superior articular facets.

2. Pedicle height (both on the right and left sides) [5]- measured at the points just opposite each other on the upper and lower margins of the pedicles in the vertical plane on its lateral aspect.

3. Pedicle width (both on the right and left sides) [5]- measured at the points on the medial and lateral surfaces of each pedicle at right angle to long axis of pedicle.

4. Interpedicle distance [5]- maximum distance between the medial surfaces of the right and left pedicles of same vertebrae. This was recorded as transverse diameter of the vertebral canal.

5. Transverse pedicle angle [10]- It is the angle between a line passing through the pedicle axis and a line parallel to the vertebral midline in the transverse plane.

6. Sagital pedicle angle [10]- It is the angle between a line passing through the pedicle axis and superior vertebral border in the sagital plane.

7. Chord length [10]- measured along the axis of the pedicle from the portion of posterior cortex of lamina to anterior cortex of body.

8. Vertebral body height [11]- measured from upper and lower aspect of vertebral body at the anterior and posterior aspects.

9. Vertebral body width [11]- transverse diameter of vertebral body at the upper, middle and lower surfaces.

10. Vertebral body anteroposterior diameter [11]- measured from anterior to posterior aspect in the middle of vertebral body.

11. Vertebral canal diameters [12]-
- Transverse diameter- Diameters measured transversely.

- Midsagital diameter- distance between posterior border of body of vertebrae and spinous process posteriorly at the midline.

- Anteroposterior diameter of lateral recess- from dorsal surface of vertebral body to the most ventral segment of the superior articular facet.

12. Shape of vertebral canal may vary from triangular to bell shaped canal [12].

All these measurements were taken using digital vernier caliper.

\section{STATISTICAL ANALYSIS}

The data were entered in Microsoft excel and were analysed. Mean, standard deviation and range measurements were analysed by degree of dispersion to find out morphometric measures in all fifth lumbar vertebrae.

\section{RESULTS}

Mean pedicle height of $L 5$ vertebrae $(8.4 \mathrm{~mm})$ on both the sides were equal. Mean pedicle length of L 5 vertebrae was more on the right side $(7.4 \mathrm{~mm})$ than on the left side $(7.2 \mathrm{~mm})$. Mean pedicle width of L5 vertebrae was more on the left side $(12.74 \mathrm{~mm})$ than the right side (12.71). Chord length of $L 5$ vertebrae was more on the right side $(33.7 \mathrm{~mm})$ than the left side $(35.8 \mathrm{~mm})$ [Table/Fig-1].

\begin{tabular}{|l|c|c|c|c|c|c|c|c|}
\hline \multirow{2}{*}{$\begin{array}{l}\text { L5 vertebrae } \\
(\mathbf{N = 8 5})\end{array}$} & \multicolumn{2}{|c|}{ Pedicle height } & \multicolumn{2}{c|}{ Pedicle length } & \multicolumn{2}{c|}{ Pedicle width } & \multicolumn{2}{c|}{ Chord length } \\
\cline { 2 - 9 } & $\begin{array}{c}\text { Right } \\
(\mathbf{m m})\end{array}$ & $\begin{array}{c}\text { Left } \\
(\mathbf{m m})\end{array}$ & $\begin{array}{c}\text { Right } \\
(\mathrm{mm})\end{array}$ & $\begin{array}{c}\text { Left } \\
(\mathbf{m m})\end{array}$ & $\begin{array}{c}\text { Right } \\
(\mathbf{m m})\end{array}$ & $\begin{array}{c}\text { Left } \\
(\mathbf{m m})\end{array}$ & $\begin{array}{c}\text { Right } \\
(\mathbf{m m})\end{array}$ & $\begin{array}{c}\text { Left } \\
(\mathbf{m m})\end{array}$ \\
\hline Mean & 8.4 & 8.4 & 7.4 & 7.2 & 12.71 & 12.74 & 33.7 & 35.8 \\
\hline $\begin{array}{l}\text { Standard } \\
\text { deviation }\end{array}$ & 3.74 & 3.78 & 8.2 & 9.1 & 1.8 & 1.6 & 6.2 & 5.9 \\
\hline Range & $5-13$ & $5-15$ & $4-9$ & $6-12$ & $11-17$ & $11-17$ & $26-41$ & $25-39$ \\
\hline
\end{tabular}

[Table/Fig-1]: Pedicle height, pedicle length, pedicle width and chord length on both sides.

Measurement of pedicle height is shown in [Table/Fig-2]. Measurement of pedicle length is shown in [Table/Fig-3]. Measurement of pedicle width is shown in [Table/Fig-4]. Chord length is shown in [Table/Fig-5]. Interpedicular distance $(23.4 \mathrm{~mm}$ ) is shown in [Table/Fig-6,7].
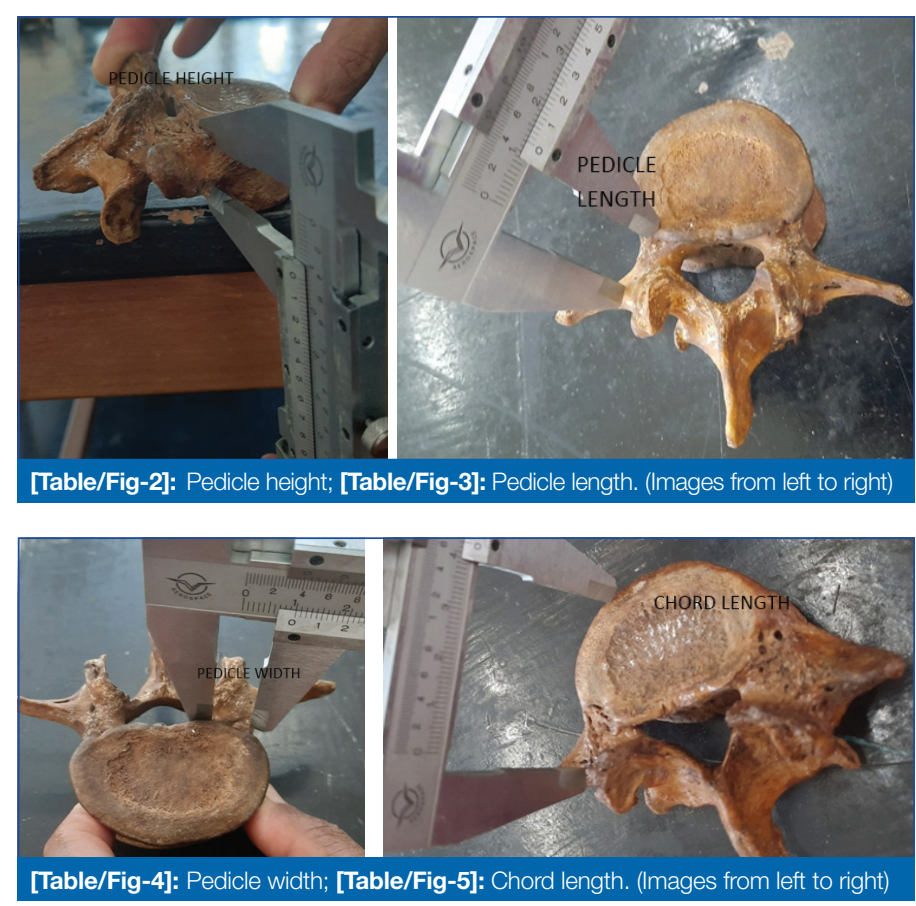

Mean transverse pedicular angle of L5 vertebrae (12.6 degree on the right side $>12.2$ degree on the left side) and mean Sagital pedicular angle (6.2 degree on the right side $>5.6$ degree on the left side) was more on the right side than the left side [Table/Fig-8]. 


\begin{tabular}{|l|c|}
\hline L5 vertebrae (N=85) & Interpedicular distance $(\mathrm{mm})$ \\
\hline Mean & 23.4 \\
\hline Standard deviation & 4.2 \\
\hline Range & $18-31$ \\
\hline [Table/Fig-6]: Interpedicular distance of L5 vertebrae. \\
\hline
\end{tabular}

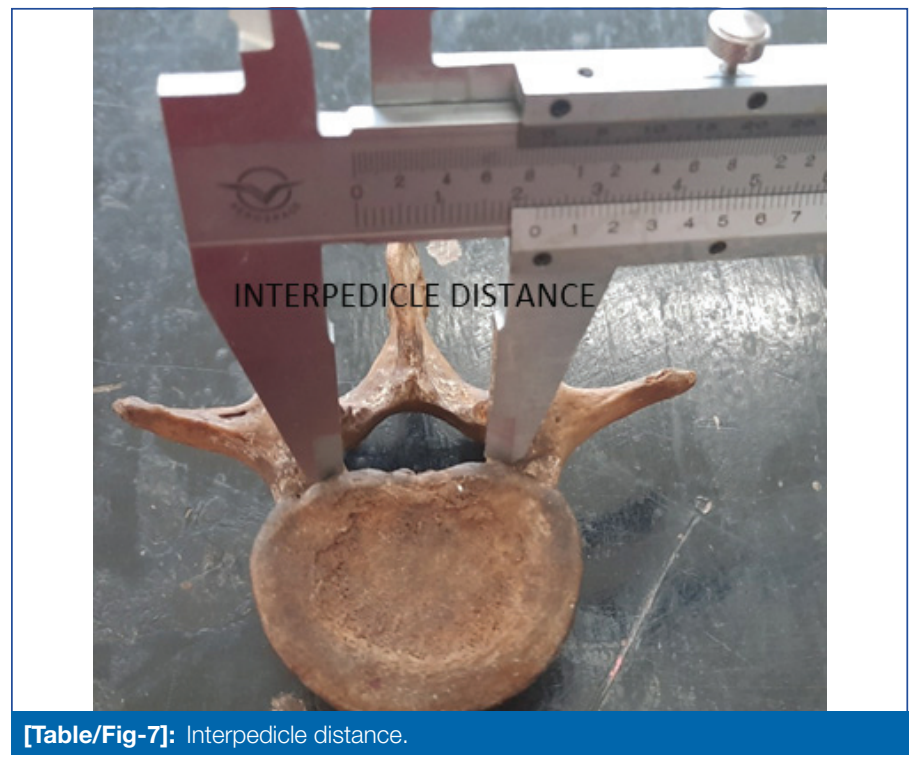

\begin{tabular}{|l|c|c|c|c|}
\hline $\begin{array}{l}\text { L5 } \\
\text { vertebrae } \\
\text { angle }\end{array}$ & $\begin{array}{c}\text { Transverse } \\
\text { pedicle angle- } \\
\text { right (degree) }\end{array}$ & $\begin{array}{c}\text { Transverse } \\
\text { pedicle angle- } \\
\text { left (degree) }\end{array}$ & $\begin{array}{c}\text { Sagital pedicle } \\
\text { angle-right } \\
\text { (degree) }\end{array}$ & $\begin{array}{c}\text { Sagital pedicle } \\
\text { angle-left } \\
\text { (degree) }\end{array}$ \\
\hline Mean & 12.6 & 12.2 & 6.2 & 5.6 \\
\hline $\begin{array}{l}\text { Standard } \\
\text { deviation }\end{array}$ & 3.4 & 3.6 & 2.4 & 2.7 \\
\hline Range & $4-26$ & $4-28$ & $1.4-8.8$ & $1.3-9$ \\
\hline
\end{tabular}

Measurement of transverse pedicular angle was shown in [Table/Fig-9]. Sagital pedicular angle was shown in [Table/Fig-10]. Mean vertebral body height of L5 vertebrae is more on the posterior aspect $(24.2 \mathrm{~mm}$ ) than the anterior aspect (23.2 $\mathrm{mm}$ ) [Table/Fig-11]. Mean vertebral body width of L5 vertebrae was more on the inferior aspect $(46.4 \mathrm{~mm})$ than on the superior $(44.2 \mathrm{~mm})$ and middle $(40.6 \mathrm{~mm})$ aspects of vertebrae [Table/Fig-12]
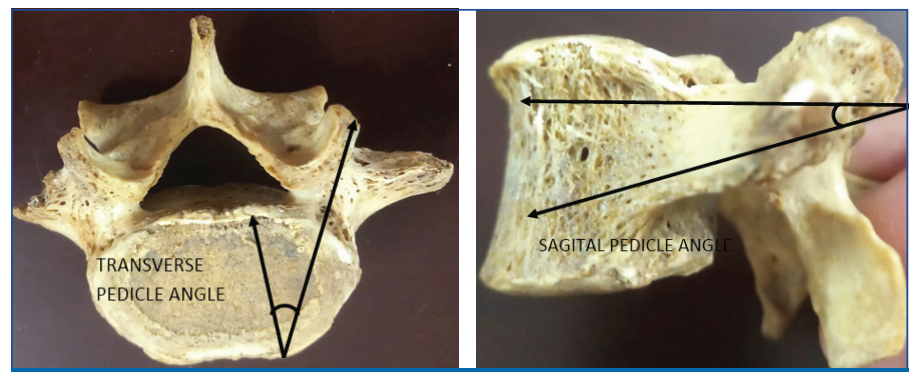

[Table/Fig-9]: Transverse pedicle angle; [Table/Fig-10]: Sagital pedicle angle. (Images from left to right)

\begin{tabular}{|l|c|c|}
\hline L5 vertebrae height & Anterior $(\mathrm{mm})$ & Posterior $(\mathrm{mm})$ \\
\hline Mean & 23.2 & 24.2 \\
\hline Standard deviation & 5.04 & 4.9 \\
\hline Range & $21-27$ & $20-27$ \\
\hline [Table/Fig-11]: Vertebral body height of L5 vertebrae $(\mathrm{N}=85)$.
\end{tabular}

\begin{tabular}{|l|c|c|c|}
\hline L5 vertebrae width & Superior $(\mathrm{mm})$ & Middle $(\mathrm{mm})$ & Inferior $(\mathrm{mm})$ \\
\hline Mean & 44.2 & 40.6 & 46.4 \\
\hline Standard deviation & 6.7 & 5.9 & 6.3 \\
\hline Range & $31-51$ & $29-46$ & $39-52$ \\
\hline
\end{tabular}

Vertebral body mean anteroposterior diameter of L5 vertebrae was $34.2 \mathrm{~mm}$ and mean vertebral canal-transverse $(23.4 \mathrm{~mm})$, midsagital $(15.1 \mathrm{~mm})$ anteroposterior $(9.1 \mathrm{~mm})$ diameters were measured and shown in [Table/Fig-13,14]. [Table/Fig-15] showed all 85 atypical lumbar vertebrae. Shape of vertebral canal was triangular in 80 L5 vertebrae [Table/Fig-16] and bell shaped in five L5 vertebrae [Table/Fig-17].

\begin{tabular}{|l|c|}
\hline L5 vertebrae anteroposterior diameter & Anteroposterior diameter (mm) \\
\hline Mean & 34.2 \\
\hline Standard deviation & 4.1 \\
\hline Range & $27-42$ \\
\hline [Table/Fig-13]: Vertebral body anteroposterior diameter of L5 vertebrae ( $\mathrm{N}=85)$.
\end{tabular}

\begin{tabular}{|l|c|c|c|}
\hline $\begin{array}{l}\text { L5 vertebrae } \\
\text { canal }\end{array}$ & $\begin{array}{c}\text { Transverse diameter } \\
(\mathrm{mm})\end{array}$ & $\begin{array}{c}\text { Midsagital diameter } \\
(\mathrm{mm})\end{array}$ & $\begin{array}{c}\text { Anteroposterior } \\
\text { diameter }(\mathrm{mm})\end{array}$ \\
\hline Mean & 23.4 & 15.1 & 9.1 \\
\hline $\begin{array}{l}\text { Standard } \\
\text { deviation }\end{array}$ & 4.9 & 3.8 & 3.2 \\
\hline Range & $21-31$ & $14-19$ & $7-11$ \\
\hline
\end{tabular}
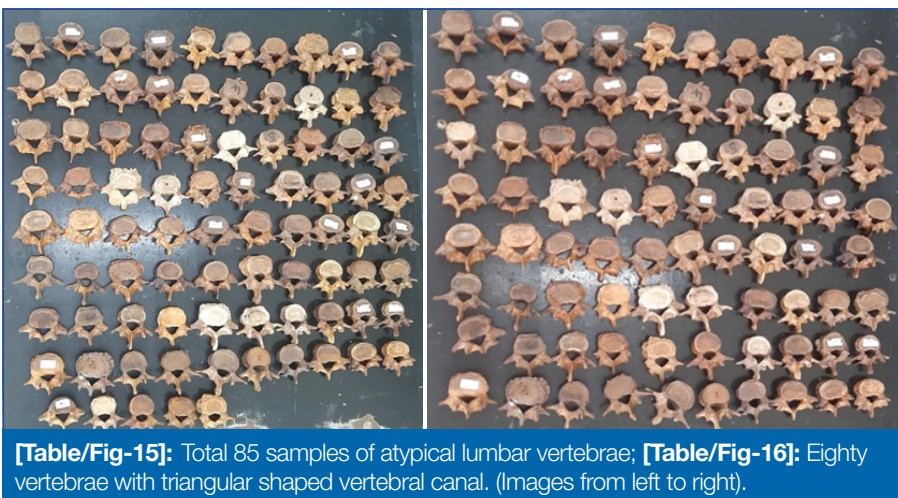

[Table/Fig-15]: Total 85 samples of atypical lumbar vertebrae; [Table/Fig
vertebrae with triangular shaped vertebral canal. (Images from left to right).

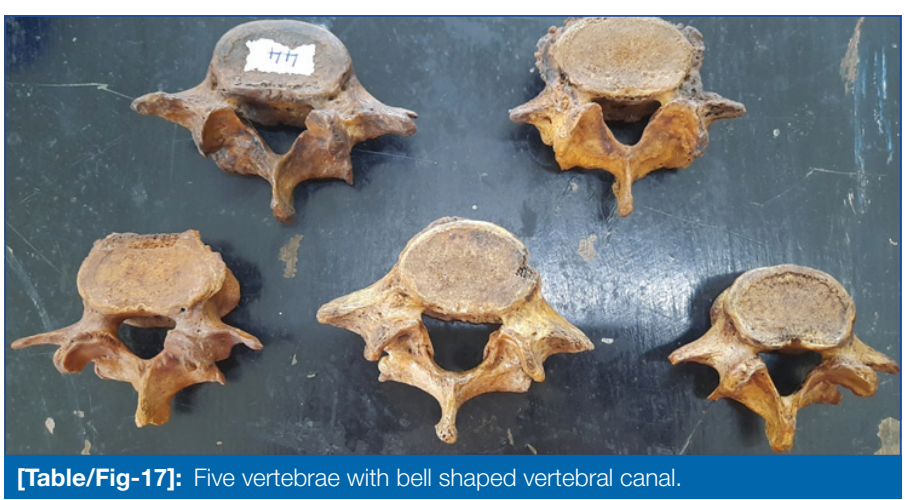

\section{DISCUSSION}

In the present study, the morphometry of dry atypical lumbar vertebrae were defined. The fifth lumbar vertebrae were identified with its atypical features. The study was done directly on the bone. Pedicle width was found to be more than the pedicle height. The study was performed for various measurements. These measurements in this study will help in finding the appropriate screw to be implanted in the pedicle for fixation and spine immobilisation.

Different studies were done on the lumbar pedicle considering its importance in weight transmission and related trauma. Various cadaveric, radiographic and osteologic studies were done for getting the morphometric data on the lumbar pedicles [4-17]. Comparison of previous author studies $[5,9,11,13,15]$ with present study (in mean \pm standard deviation) was shown in [Table/Fig-18] which showed mean pedicle height and mean pedicle width.

Singel TC et al., studied sixty lumbar vertebrae and observed mean height was $13.4 \mathrm{~mm}$, mean width was $18.2 \mathrm{~mm}$ for males and mean height was $13.25 \mathrm{~mm}$ for males, mean width was $19.25 \mathrm{~mm}$ 


\begin{tabular}{|l|c|c|c|c|}
\hline $\begin{array}{l}\text { Author study } \\
\text { (year) }\end{array}$ & $\begin{array}{c}\text { Mean pedicle } \\
\text { height-right } \\
(\mathrm{mm})\end{array}$ & $\begin{array}{c}\text { Mean pedicle } \\
\text { height-left } \\
(\mathrm{mm})\end{array}$ & $\begin{array}{c}\text { Mean pedicle } \\
\text { width-right } \\
(\mathrm{mm})\end{array}$ & $\begin{array}{c}\text { Mean pedicle } \\
\text { width-left } \\
(\mathrm{mm})\end{array}$ \\
\hline $\begin{array}{l}\text { Wankhede HA } \\
\text { et al., (2014) [5] }\end{array}$ & $1.28 \pm 0.16$ & $1.25 \pm 0.15$ & $1.45 \pm 0.24$ & $1.46 \pm 0.25$ \\
\hline $\begin{array}{l}\text { Tiwari A et al., } \\
\text { (2015) [9] }\end{array}$ & $14.5 \pm 1.86$ & $14.5 \pm 1.57$ & $17.7 \pm 1.71$ & $17.7 \pm 1.71$ \\
\hline $\begin{array}{l}\text { Patil DK and } \\
\text { Bhuiyan PS, } \\
\text { (2014) [11] }\end{array}$ & $13.96 \pm 1.34$ & $13.9 \pm 1.34$ & $8.41 \pm 1.62$ & $8.57 \pm 1.62$ \\
\hline $\begin{array}{l}\text { Chandini G et } \\
\text { al., (2014) [13] }\end{array}$ & $14 \pm 2$ & $13 \pm 1$ & $14 \pm 2$ & $14 \pm 2$ \\
\hline $\begin{array}{l}\text { Choubisa L } \\
\text { and Babel H, } \\
\text { (2018) [15] }\end{array}$ & $13.55 \pm 2.1$ & $13.43 \pm 2.15$ & $12.14 \pm 2.9$ & $12.06 \pm 2.45$ \\
\hline \multicolumn{7}{|l|}{ Present study } & $8.4 \pm 3.74$ & $8.4 \pm 3.78$ & $12.71 \pm 1.8$ & $12.74 \pm 1.6$ \\
\hline
\end{tabular}

for females in L5 vertebrae [6]. More width than height was found in there study $L 5$ vertebrae. Transpedicular approaches are widely used surgical procedures for bone biopsy, bone grafting, vertebroplasty and pedicle screw fixation. In pedicle screw fixation, the screw is passed through the posterior aspect of the pedicle into the body of the vertebrae interiorly. Because the success of this technique depends on the ability of the screw to obtain strength within the vertebral body, the choice of the screw to be used is determined by the minimum diameter of the pedicle [9].

Seema et al., studied plain anteroposterior radiographs of 100 adult males of ages starting from 20-60 and found mean horizontal diameter of $L 5$ pedicle was $13.98 \mathrm{~mm}$ and mean vertical diameter was $17.63 \mathrm{~mm}$ and mean interpedicular distance at L5 was $30.78 \mathrm{~mm}$ [14]. Avuthu S et al., studied one hundred CT scans from T9 level to L5 vertebrae and found pedicle width of L5 vertebrae was $12.26 \mathrm{~mm}$ in males and $13.03 \mathrm{~mm}$ in females [16]. Chord length was $40.17 \mathrm{~mm}$ in males and $40.01 \mathrm{~mm}$ in females. Kapoor $Y$ et al., studied six sets of lumbar vertebrae and observed mean interpedicular distance was $21.5 \mathrm{~mm}$, sagital diameter of vertebral canal was $14.75 \mathrm{~mm}$ and anteroposterior diameter of lateral recess was $8.95 \mathrm{~mm}$ in L5 vertebrae [12]. It was found interpedicular distance and sagital diameter of vertebral canal increased in L5 vertebrae and narrowing of the vertebral canal occurring at L2-L4 level which may lead to compression of spinal cord and its nerve roots in general population.

Azuo O et al., studied 298 lumbar vertebrae and observed the following measurements in L5 vertebrae-mean pedicle length was $3.17 \mathrm{~mm}$ in males and $3.21 \mathrm{~mm}$ in females, interpedicular distance was $23.6 \mathrm{~mm}$ in males and $24.26 \mathrm{~mm}$ in females, Anteroposterior Distance (APD) was $35.16 \mathrm{~mm}$ in males and $36.08 \mathrm{~mm}$ in females, Midsagital Distance (MSD) was $18.94 \mathrm{~mm}$ in males and $18.67 \mathrm{~mm}$ in females, MSD/APD was 0.54 in males and 0.53 in females. This ratio-Torg ratio was found relevant in lumbar canal stenosis [17].

Urritia VE et al., studied cross sectional study in sixty cadavers [18]. The cadavers were evaluated by fluoroscopy and CT scan from L1 to L5 vertebrae. In CT scan they found mean \pm standard deviation values of pedicle length was $17.23 \pm 1.35$, pedicle width was $14.36 \pm 1.85$ in $\mathrm{L} 5$ vertebrae with increase in pedicle width and decrease in pedicle length of $L 5$ as compared to $L 1$. mean \pm standard deviation values of vertebral body anteroposterior diameter 37.28 \pm 5.04 , transverse diameter $51.46 \pm 6.44$ and spinal canal transverse diameter $29.78 \pm 3.5$ were found in $L 5$ vertebrae. By fluoroscopy, mean \pm standard deviation values of pedicle length was $37 \pm 3.42$, pedicle width was $25.56 \pm 2.12$ and pedicle height was $2.4 \pm 2.41$ in L5 vertebrae. Mean \pm standard deviation values of vertebral body anteroposterior diameter $78.55 \pm 5.65$ and body height was $59.88 \pm 4.4$. Author in his study concluded that CT scanning evaluation is the gold standard in determining the feasibility of pedicle screw insertion and fluoroscopy is used only to obtain the proper entry points and angulations for screw insertion intraoperatively [18].

In the present study, various morphometric measurements of L5 vertebrae were observed and were similar to previous studies $[5,9,11,13,15]$. The measurements may be useful before planning the pedicle screw fixation. However, it has been found that the pedicle height is always greater than pedicle width. The present study agrees with this finding. In deciding pedicle screw diameter, the pedicle height carries less importance than width. Wrong placement of pedicle screw may injure vessels and spinal cord and hence care should be taken while placing screws on the pedicle.

Comparison of previous author studies $[10,11]$ with present study was shown in [Table/Fig-19] which showed transverse pedicular angle and sagital pedicle angle. Mean Transverse pedicular angle of L5 vertebrae is more on the right side than the left side in the present study. This was similar to previous studies $[10,11]$. Sagital pedicle angle is important in accurate screw placement as inferior margin of the screw may result in injury to nerve root. Safest length of any screw that can be used for pedicle screw fixation is determined by chord length. It may injure vital organs and major blood vessels which lie anterior to vertebral body if the screw is not placed in correct position. Mean sagital pedicular angle and chord length of $\mathrm{L} 5$ vertebrae are more on the right side than the left side in present study. This was similar to previous study [11]. Anteroposterior diameter was more in L5 vertebrae. Midsagital diameter if $<10 \mathrm{~mm}$ may produce spinal canal stenosis.

\begin{tabular}{|l|c|c|c|c|}
\hline $\begin{array}{l}\text { Author's } \\
\text { study (year) }\end{array}$ & $\begin{array}{c}\text { Transverse } \\
\text { pedicle angle- } \\
\text { right (degree) }\end{array}$ & $\begin{array}{c}\text { Transverse } \\
\text { pedicle angle- } \\
\text { left (degree) }\end{array}$ & $\begin{array}{c}\text { Sagital pedicle } \\
\text { angle-right } \\
\text { (degree) }\end{array}$ & $\begin{array}{c}\text { Sagital } \\
\text { pedicle angle- } \\
\text { left (degree) }\end{array}$ \\
\hline $\begin{array}{l}\text { Chawla H et } \\
\text { al., (2013) } \\
\text { [10] }\end{array}$ & $\begin{array}{c}25.7 \text { in males } \\
\text { and } 24 \text { in } \\
\text { females }\end{array}$ & $\begin{array}{c}25.67 \text { in males } \\
\text { and } 23.8 \text { in } \\
\text { females }\end{array}$ & ---- & --- \\
\hline $\begin{array}{l}\text { Patil DK and } \\
\text { Bhuiyan PS } \\
\text { (2014) [11] }\end{array}$ & 11.79 & 11.67 & 4.78 & 4.67 \\
\hline $\begin{array}{l}\text { Present } \\
\text { study }\end{array}$ & 12.6 & 12.2 & 5.6 & 6.2 \\
\hline \\
[Table/Fig-19]: Comparison of trans and sagital pedicle angle of previous Author's \\
studies with present study [10,11].
\end{tabular}

\section{Limitation(s)}

The present study was performed only in 85 atypical lumbar vertebrae. Larger sample size may reveal accuracy in the study.

\section{CONCLUSION(S)}

Pedicle morphometric measurements show significant variations and this can be due to different characteristics of population studied. Proper preoperative evaluation should be done to precisely ascertain pedicle size before surgery so that improper use of screws can be avoided. Understanding the morphometry of the pedicle and knowledge about the nearby structures is important for radiologists and orthopaedic surgeons to select appropriate pedicle screws for operative repair and to avoid postoperative complications. To identify the cause of low backache, knowledge about lumbar vertebrae and its pedicle is important.

\section{REFERENCES}

[1] Standring S. Gray's Anatomy: The Anatomical Basis of Clinical Practice. In: The back. 39 ${ }^{\text {th }}$ Edition: London. Elsevier Churchill Livingstone. 2005;748-749.

[2] Datta AK. Essentials of Human Anatomy: Part 1.In: Lumbar vertebrae. $8^{\text {th }}$ Edition: Calcutta. Current Books International. 2008;143-44.

[3] Pal GP, Routal RV. Transmission of weight thro'the lower thoracic and lumbar regions of the vertebral column in man. J Anat.1987;152:93-105.

[4] Hisang JK, Furman MB. Spinal stenosis. Available from at http://emedicine. medscape.com/article/1913265.

[5] Wankhede HA, Jadhav SS, Katti AS, Herekar NG. Morphometric study of the pedicle of the dried adult human lumbar vertebrae. I J Anat Phy and Bioc. 2014;1(1):01-05

[6] Singel TC, Patel MM, Gohil DV. A study of width and height of lumbar pedicles in Saurashtra region. J Anat Soc India. 2004;53(1):04-09.

[7] Aruna N, Rajeshwari T. A study of Lumbar pedicle size in South Indians. Anat Karn. 2011;5(2):69-73. 
[8] Nelson MA. Lumbar canal stenosis. J Bone and Joint Surg. 1973;556(3):506-12.

[9] Tiwari A, Pandey S, Deepak CN. Morphometric study of atypical lumbar vertebrae and its physiological correlation. I J Med Sci and Pub Health. 2015;4(2):262-65.

[10] Chawla H, Sharma M, Kochha S, Abhaya A, Sahns D, Gupta R. Importance of TPAandCL of lumbar pedicle in Screw placement: A CT Scan study on North west Indian population. Eur J Anat. 2013;17(4):230-36.

[11] Patil DK, Bhuiyan PS. A morphometric study of pedicles of dry human typical lumbar vertebrae. I J Bas and App Med Res. 2014;3(3):428-32.

[12] Kapoor Y, Sherke AR, Krishnaiah M, Suseelamma D. Morphometry of the Lumbar vertebrae and its clinical significance. Sch J App Med Sci. 2014;2(3c):1045-52.

[13] Chandni G, Poonam K, Aravind KP, Antony SD. Morphometrical study of Pedicles in Lumbar vertebrae and its clinical significance. J Surg Acad. 2014;4(1):37-40
[14] Seema, Verma P, Singh M. Morphometric study of pedicles of Lumbar vertebrae in adult Punjabi males. Int J Anat Res. 2016;4(2):2401-04.

[15] Choubisa L, Babel H. Morphometric study of pedicles of dried adult human lumbar vertebrae in Udaipur Zone. Int J Anat Res. 2018;6(3.3):5660-66.

[16] Avuthu S, Salian PV, Kotian P, Shetty BS. Computed Tomographic morphometry of thoracic and lumbar pedicles in South Indian population. Asian J Pharm Hea Sci. 2014;4(2):995-1000.

[17] Azuo O, Komolafe OA, Ofusori DA, Ajayi SA, Naidu ECS, Abiodun AA Morphometric study of Lumbar vertebrae in Adult South African Subjects. I J Morphol. 2016;34(4):1345-51.

[18] Urritia VE, Eliozondo ORE, De la Garza CO, Guzman LS. Morphometry of pedicle and vertebral body in a Mexican population by CT and Fluoroscopy. Int J Mophol. 2009;27(4):1299-303.

\section{PARTICULARS OF CONTRIBUTORS}

1. Associate Professor, Department of Anatomy, PSG Institute of Medical Sciences and Research, Coimbatore, Tamil Nadu, India.

2. Professor and Head, Department of Anatomy, Karpagam Institute of Medical Sciences and Research, Coimbatore, Tamil Nadu, India.

\section{NAME, ADDRESS, E-MAIL ID OF THE CORRESPONDING AUTHOR:}

Dr. Manicka Vasuki Kandavadivelu Anaimalai,

Associate Professor, Department of Anatomy, PSG Institute of Medical Sciences and Research, Coimbatore-641004, Tamil Nadu, India.

E-mail: vasukikalyan01@gmail.com
PLAGIARISM CHECKING METHODS: [Jain Het al.]

- Plagiarism X-checker: Apr 13, 2021

- Manual Googling: Jun 26, 2021

- iThenticate Software: Jul 30, 2021 (15\%)

\section{AUTHOR DECLARATION:}

- Financial or Other Competing Interests: None

- Was Ethics Committee Approval obtained for this study? Yes

- Was informed consent obtained from the subjects involved in the study? No

- For any images presented appropriate consent has been obtained from the subjects. No

Date of Submission: Apr 02, 2021

Date of Peer Review: Jun 15, 2021

Date of Acceptance: Jul 09, 2021

Date of Publishing: Oct 01, 2021 